Jurnal Sosial Ekonomi dan Kebijakan Pertanian

http://journal.trunojoyo.ac.id/agriekonomika

Agriekonomika Volume 6, Nomor 2, 2017

\title{
HARMONISASI KEPEMIMPINAN DI KABUPATEN WONOSOBO DALAM KEBIJAKAN PEMBANGUNAN PERTANIAN BERKELANJUTAN
}

\author{
Nur Saudah Al Arifa D \\ Jurusan Agribisnis Universitas Nahdlatul Ulama Yogyakarta \\ Received: 24 Juli 2017; Accepted: 12 November 2017; Published: 14 November 2017 \\ DOI: http://dx.doi.org/10.21107/agriekonomika.v6i2.3035
}

\begin{abstract}
ABSTRAK
Wonosobo merupakan kabupaten yang mempunyai petensi besar di sektor pertanian. Lebih dari 50\% penduduk Kabupaten Wonosobo berprofesi sebagai petani. Isu tentang pertanian dan kesejahteraan petani selalu menjadi isu sentral ketika memasuki masa pemilihan kepala daerah. Di era otonomi daerah, setiap kepala daerah mempunyai kewenangan dalam menjalankan tata kelola pemerintahan sesuai dengan potensi sumberdaya yang dimiliki. Tulisan ini merupakan suatu kajian analitik berdasarkan literatur yang bertujuan untuk mengupas sejauh mana pengaruh penerapan otonomi daerah di Kabupaten Wonosobo dalam hal kebijakan pembangunan pertanian berkelanjutan, serta memberi gambaran kelebihan serta kelemahan otonomi daerah dalam tata kelola pemerintahan di sektor pertanian. Metode yang digunakan adalah dengan metode kualitatif serta kajian pustka. Data yang digunakan adalah data sekunder dari BPS dan Bappeda. Adapun hasil kajian menunjukkan bahwa saat ini bahwa harmonisasi kepemimpinan dalam hal pengambilan kebijakan kepala daerah di Wonosobo belum berjalan sesuai harapan, ego dan gaya kepemimpinan menjadi alasan mengapa setiap pergantian periode cenderung berganti pula kebijakan yang dijalankan. Rekomendasi dari penelitian ini adalah agar masing-masing stakeholder terkait melakukan sinkronisasi kebijakan dan program dalam rangka pembangunan pertanian yang berkelanjutan.
\end{abstract}

Keywords: Harmonisasi, Kepemimpinan, Kebijakan, Pembangunan Pertanian

\section{HARMONIZATION OF LEADERSHIP IN WONOSOBO REGENCY IN SUSTAINABLE AGRICULTURE DEVELOPMENT POLICY}

\begin{abstract}
Wonosobo is a very potential regency in agricultural sector. There are more than $50 \%$ of the population are farmers. Issue about agriculture and farmers' welfare always places the central issue in the election era. In regional autonomy, every district leader has an authority in carrying out their government urban planning in accordance with their resource potency. This paper is a literature analytical study which aims to analyze how far is the influences of the regional autonomy implementation in Wonosobo. It focuses in the continuity of agricultural development policy and also gives the illustration of the strength and weaknesses in their government urban planning in agriculture sector. The method used is by qualitative method and literature review. The data used are secondary data from BPS and Bappeda. The result shows that the harmonization of leaders in taking the leader policy in Wonosobo has not run as the hope before, the ego and style of leadership of the district head becomes the main reason why every changing period often changes the policy. The recommendation of this research is that each relevant stakeholder must synchronizes policies and programs for sustainable agricultural development.
\end{abstract}

Keywords : Harmonization, Leader, Policy, Agriculture Development.

$\begin{array}{ll} & \text { Corresponding author: } \\ \text { Address } & \text { : Cawet Rt } 02 \text { RW } 01 \text { Suren Gede, Kec. } \\ & \text { Kertek, Kab. Wonosobo } \\ \text { Email } \quad: \text { nur.saudah.ad@unu-jogja.ac.id } \\ \text { Phone } \quad: 085292591282\end{array}$




\section{PENDAHULUAN}

Dalam rangka mewujudkan pembangunan pertanian berkelanjutan yang berdaulat dan mandiri, serta menghadapi besarnya tantangan dalam pemanfaatan potensi sumberdaya pangan, maka diperlukan suatu arah kebijakan pembangunan pertanian di daerah lokal yang terintegrasi dengan kebijakan Provinsi dan Pemerintah Pusat.

Sektor pertanian mempunyai peran yang sangat strategis, disamping sebagai sumber penghasil devisa yang besar, sektor pertanian juga merupakan sumber ekonomi bagi bagi sebagian besar penduduk Indonesia, dan merupakan sektor yang paling banyak dalam penyerapan tenaga kerja. Pada umumnya sebagian besar adalah tenaga kerja tidak terdidik, tidak memiliki ketrampilan dan pendapatan yang tidak merata. Atas kondisi inilah yang menyebabkan bargaining power yang dimiliki oleh para petani kita sangat lemah, sehingga nilai jual dari produk juga sangat berpengaruh terhadap kondisi ini (Esther dkk, 2015).

Kebijakan pembangunan bidang pertanian khususnya dalam penyelenggaraan pangan nasional telah diejawantahkan dalam Undang-Undang No 18 tahun 2012. Secara umum undang-undang ini sudah mengatur pembagian peran masing-masing tingkat pemerintahan dalam pembangunan ketahanan pangan nasional sesuai dengan tugas, tanggung jawab dan pembagian wewenang dalam mengeksekusi pengaturan kebijakan pembangunan pertanian.

Wicaksono (2012), berpendapat bahwasanya pangan merupakan isu sentral dalam kehidupan berbangsa dan bernegara, sehingga perkara ketahanan pangan seharusnya dijadikan prioritas. Salah satu yang menjadi kendala dalam mewujudkan kemandirian pangan di Indonesia saat ini adalah terkait dengan adanya fakta bahwa pertumbuhan permintaan pangan yang lebih cepat dari pertumbuhan penyediaannya. Permintaan yang meningkat cepat tersebut merupakan resultante dari peningkatan jumlah penduduk, per- tumbuhan ekonomi, peningkatan daya beli masyarakat dan perubahan selera.

Lebih lanjut menurut Wicaksono (2012) bahwa seorang pemimpin setidaknya dia mampu melaksanakan political mapping untuk internal dan eksternal organisasi kemudian dilakukan analisis dengan parameter visi, misi, rencana strategis dan desain kebijakan makro. Hal tersebut dimaksudkan agar seorang pemimpin dapat secara cermat mengetahui apa yag menjadi hambatan dan peluang, sehingga dapat mempermudah dalam perencanaan aksi yang lebih detail. Karena pada dasarnya pemimpin tersebut yang mempunyai andil besar dalam pengambilan kebijakan.

Konstitusi dalam UU Pemerintan Daerah (Pemda) merupakan jaminan adanya sistem otonomi daerah. Akan tetapi, esensi dari otonomi daerah idealnya tidak melampaui batas sehingga dimaknai sebagai pemberian kedaulatan/hak mutlak oleh pemerintah pusat kepada pemerintah daerah untuk membuat dan menghasilkan kebijakan dan keputusan menurut tujuan, sasaran, dan kepentingan aktor-aktor politik di daerah (Kore, 2015). Maka, demi kepentingan publik yang lebih besar, hendaknya para pemimpin dan para pengampu kebijakan di daerah sudah saatnya menanggalkan ego pribadi, ego kelompok serta egosentris kedaerahan untuk kebermanfaatan yang lebih besar guna mewujudkan integrasi kebijakan penyelenggaraan pangan agar dapat saling sinergi dan tidak saling tumpang tindih.

Perumusan kebijakan ketahanan pangan di Indonesia telah di amanatkan dalam UU tentang pangan pada tahun 1996, dan dikuatkan melalui Peraturan Pemerintah nomor 68 tahun 2001. Puncaknya, pada pertemuan Pangan dunia tahun 2002 (WorldFood Summit- five years later: WFS - fyl). Pertemuan tersebut melatarbelakangi lahirnya Keputusan Presiden (Keppres) RI Nomor 132 tahun 2001 tentang Dewan Ketahanan Pangan (DKP) yang bertugas diantaranya untuk merumuskan kebijakan di bidang ketahanan pangan nasional yang meliputi aspek ketersediaan, distribusi, dan konsumsi serta 
mutu, gizi, dan keamanan pangan; dan melaksanakan evaluasi dan pengendalian pemantapan ketahanan pangan nasional.

Riset mengenai Harmonisasi Kebijakan Pangan Nasional dan Daerah pernah dikaji oleh Hermanto (2013), penelitian tersebut merujuk Peraturan Pemerintah No. 38 Tahun 2007 yang berisi penjelasan Pembagian Urusan Pemeritahan antara Pemerintah Pusat, Pemerintah Provinsi (Pemprov), dan Pemerintah Daerah (Pemda) Kabupaten/Kota, berdasarkan UU tersebut dapat disimpulkan bahwa bahwa ketahanan pangan merupakan urusan wajib dilaksanakan oleh Pemerintah Daerah Provinsi dan Pemerintah Daerah Kabupaten dan Kota. Akan tetapi urusan bidang pertanian menurut peraturan pemerintah ini dimasukkan ke dalam urusan pilihan. Urusan pilihan inilah yang nantinya berpotensi untuk meningkatkan kesejahteraan masyarakat sesuai dengan kondisi, potensi, serta kekhasan yang menjadi unggulan daerah di daerah tersebut. Sehingga hal ini harus disikapi dengan bijak oleh para stakeholder terkait.

Harmonisasi kepemimpinan dalam pengambilan kebijakan pertanian secara terpadu di kabupaten Wonosobo dimaksudkan agar penyelenggaraan pangan di Wonosobo dapat berjalan secara optimal dan terarah sesuai dengan sumberdaya lokal yang dimiliki. Salah satu bentuk implementasi kebijakan otonomi daerah adalah pengaturan kebijakan tata kelola pemerintahan sesuai dengan kebijakan yang ditetapkan oleh kepala daerah, di kabupaten Wonosobo kebijakan itu diwujudkan dalam bentuk penyusunan Struktur Organisasi dan Tata Kelola (SOTK). Salah satu hambatan dalam harmonisasi kepemimpinan adalah rasa ego yang ada dalam diri setiap pemimpin. Masing-masing pemimpin di daerah punya arah kebijakan yang dibawa, kebijakan yang dibawa oleh kepala daerah sebelumnya belum tentu akan diteruskan oleh kepala daerah selanjutnya, dan dengan perpindahan tampuk kepemimpinan, pertanyaan dasar yang muncul adalah apakah formasi Struktur Organisasi dan Tata Kelola (SOTK) akan sama dengan formasi yang ditetapkan dalam kepemimpinan sebelumnya, ataukah akan ada perombakan saat pergantian tampuk kekuasaan?.

Berdasarkan penelitian Mayrowani (2012), hasil penelitian menunjukkan bahwa pembangunan di bidang pertanian selama ini dianggap oleh sebagian birokrasi dan legislator lokal sebagai bidang yang cost-center sehingga membutuhkan investasi yang besar akan tetapi returnnya cukup lama. Alasan cost- center dan return menjadi dasar pertimbangan dan menyebabkan mengapa isu pentingnya pembangunan pertanian kurang menarik perhatian dan menjadi prioritas bagi sebagian besar pembuat kebijakan daerah.

Gejala tersebut sudah mulai nampak terlihat di kabupaten Wonosobo, sehingga meskipun sektor pertanian merupakan penopang utama struktur perekonomian masyarakat, namun sektor ini dalam praktiknya belum menjadi prioritas utama dalam pembangunan daerah. Pun ketika terjadi perombakan dalam Struktor Organisasi dan Tata Kelola Pemerintahan (SOTK), sektor pertanian menjadi sektor yang paling merasakan dampak signifikan akibat mengalami perampingan, sehingga hal tersebut berdampak pada perampingan anggaran (Cut of Budgeting) di sektor pertanian.

Oleh karena itu, tujuan dari penelitian ini adalah: (1) mengupas sejauh mana pengaruh penerapan otonomi daerah di Kabupaten Wonosobo dalam hal kebijakan pembangunan pertanian agar dapat berkelanjutan (2) memberi gambaran kelebihan serta kelemahan otonomi daerah dalam tata kelola pemerintahan.

\section{METODE PENELITIAN}

Metode yang digunakan dalam penelitian ini adalah metode kualitatif serta kajian pustaka yang dianalisis lebih lanjut untuk memperkuat penjelasan. Jenis data yang digunakan adalah data sekunder yang diambil dari berbagai sumber diantaranya Badan Pusat Statistik (BPS), Badan Perencanaan Pembangunan Daerah (BAPPEDA). Batasan Penelitian hanya men- 
cakup Perekonomian Wonosobo dengan variabel yang menjadi bahan penelitian adalah PDRB Kabupaten Wonosobo dengan wilayah referensi Provinsi Jawa Tengah.

\section{HASIL DAN PEMBAHASAN \\ Pengaruh Penerapan Otonomi Daerah di Kabupaten Wonosobo dalam Kebijakan Pembangunan Pertanian}

Kebijakan yang diambil oleh pemimpin daerah dapat mempengaruhi cepat lambatnya pembangunan pertanian serta akses masyarakat kepada pangan. Untuk mewujudkan ketahanan pangan dilakukan pengembangan sumber daya manusia yang meliputi edukasi berupa pendidikan dan pelatihan di bidang pertanian, serta penyebarluasan ilmu pengetahuan dan teknologi (IPTEK) di bidang pertanian.

Menurut Rachbini (2010) untuk memastikan suatu kondisi ekonomi apakah akan berjalan baik ataukah tidak, dalam jangka panjang, perlu kepastian pula dalam kebijakan dengan sinyal dan arah yang jelas pula. Bahkan, sangat diperlukan kebijakan induk, yang memandu seluruh dinamika kebijakan departemen dan daerah. Tanpa itu, kepastian arah perekonomian jangka panjang masih dipertanyakan, bahkan diragukan dan membingungkan. Demikian pula di kebijakan yang diterapkan di Kabupaten Wonosobo, idealnya perencanaan pembangunan sektor pertanian harus lebih terarah karena sektor pertanian inilah yang menjadi tumpuan utama perekonomian masyarakat Wonosobo.

Pembangunan pertanian berdimensi luas dan melibatkan seluruh aspek dan sektor pembangunan lainnya, keberhasilan pembangunan pertanian sangat ditentukan tidak hanya oleh performa sektor pertanian semata, namun juga oleh sektor lainnya yang menunjang kegiatan pertanian.

Penerapan kebijakan otonomi daerah sejatinya merupakan kesempatan besar bagi para kepala daerah untuk berinovasi dalam penyelanggaran pemerintahan berdasarkan dengan potensi lokal yang dimilikinya. Kepala daerah mempunyai kewenangan yang sangat longgar dalam membuat kebijakan untuk mempercepat pembangunan kesejahteraan bagi masyarakatnya. Untuk mencapai kesejahteraan tentunya membutuhkankan langkah strategis dalam perumusan pembuatan kebijakan.

Badan Pusat Statistik (BPS) Provinsi Jawa Tengah mencatat bahwa Kabupaten Wonosobo termasuk dalam tiga (3) daerah yang memiliki memiliki PDRB per kapita terendah di Jawa Tengah, data tahun 2013 menunjukkan angka kemiskinan di Kabupaten Wonosobo sebesar 22,08\%, angka tersebut jauh lebih tinggi bila dibandingkan dengan angka kemiskinan Provinsi Jawa tengah yang ada di angka $14,44 \%$.

Kabupaten Wonosobo dalam jangka waktu 2000-2015 mengalami tiga kali periode pergantian kepala daerah melalui perhelatan pesta demokrasi. Dimana selama dua periode pemilu 2005-2010 dan 2010-2015 dimenangkan oleh bupati incumbent, dan kini di tahun 2015-2020 dipimpin oleh bupati yang baru.

Ada yang unik, bahwa selama selama dua periode kepemimpinan incumbent, perubahan kebijakan tata kelola pemerintahan atau yang disebut Struktur Organisasi dan Tata Kelola (SOTK) justru terjadi di akhir masa jabatan. Kebijakan perubahan SOTK yang diterapkan di Kabupaten Wonosobo ini sangat memberikan pengaruh terhadap kebijakan pembangunan pertanian. Sebelumnya, pada periode 2005-2014 struktur dinas yang berkaitan dengan pertanian dibagai menjadi 3 dinas, yaitu 1) Pertanian dan Tanaman Pangan; 2) Dinas Peternakan dan Perikanan; dan 3) Dinas Kehutanan dan Perkebunan. Pasca diberlakukannya SOTK maka dinas yang berkaitan dengan sektor pertanian dirampingkan menjadi satu yaitu menjadi Dinas Pertanian dan Perikanan.

Kebijakan SOTK di akhir masa periode jabatan tentunya memberikan dampak yang signfikan pada pola kerja dan juga pola koordinasi. Kondisi yang seperti itu semestinya harus disikapi dengan bijak oleh kepala daerah saat ini. Oleh karena 
itu, harmonisasi kepemimpinan menjadi penting dilakukan bagi Bupati terpilih pada periode 2015-2020 yang tentunya mempunyai visi misi tersendiri dalam pembangunan sektor pertanian. Pilihan kebijakan yang mendasar adalah apakah akan tetap melanjutkan langkah kebijakan yang diambil pemimpin sebelumnya, ataukah justru akan membuat formula baru dalam SOTK. Harmonisasi tentunya menjadi jalan tengah agar terjadi sinkronisasi program dalam tata kelola pemerintahan pada sektor pertanian pada khususnya dan sektor lainnya pada umumnya.

\section{Kabupaten Wonosobo dan PDRB Ter- endah Jawa Tengah}

Salah satu indikator atau parameter yang digunakan untuk mengukur apakah penerapan otonomi daerah berhasil mensejahterakan atau tidak, secara umum dapat dilihat dari berapa banyak PDRB yang diterima. Berdasarkan data perkembangan PDRB Provinsi Jawa Tengah, dapat dilihat bahwa Kabupaten Wonosobo menempati posisi ke-dua setelah Kabupaten Tegal. Itu artinya Kabupaten Wonosobo termasuk dalam kategori daerah tertinggal di Provinsi Jawa Tengah. Berikut merupakan Gambar 1 data PDRB Wonosobo dengan wilayah referensi Jawa Tengah.

Menyikapi hal tersebut, agar dapat keluar dari tiga besar Kabupaten dengan PDRB terendah, tentunya pemerintah Ka- bupaten Wonosobo harus berjuang lebih keras untuk dapat meningkatkan PDRB, salah satunya ialah dengan pembenahan pembangunan sektor pertanian sebagai sektor utama dalam struktur perekonomian Kabupaten Wonosobo serta membangun sektor penunjang lainnya yang berpotensi meningkatkan pendapatan asli daerah.

\section{Sumbangsih Sektor Pertanian Terhadap PDRB Kabupaten Wonosobo}

Dibandingkan dengan sektor lainnya, maka sektor pertanian masih menjadi leader dalam sumbangshnya terhadap PDRB kabupaten Wonosobo. Kedudukan sektor pertanian dalam menopang pembangunan ekonomi Wonosobo secara signifikan dapat dilihat dari sumbangsih PDRB yang besar hingga rata-rata mencapai diatas 44\% terhadap total PDRB Wonosobo, dan merupakan sumbangan terbesar. Besarnya prosentase ini menunjukkan bahwa sektor pertanian masih menjadi sumber pencaharian utama bagi masyarakat Wonosobo. Meskipun kecenderungan kontribusi sektor pertanian terhadap PDRB total kabupaten mengalami penurunan setiap tahunnya, adapun kontribusi sektor pertanian dapat dilihat pada Gambar 2.

Berdasarkan Gambar 2, perkembangan PDRB sektor pertanian sejak 2003 hingga 2013 kecenderungannya masih kurang stabil. Tahun 2003 kontribusi sektor pertanian mencapai $44,69 \%$ dan di

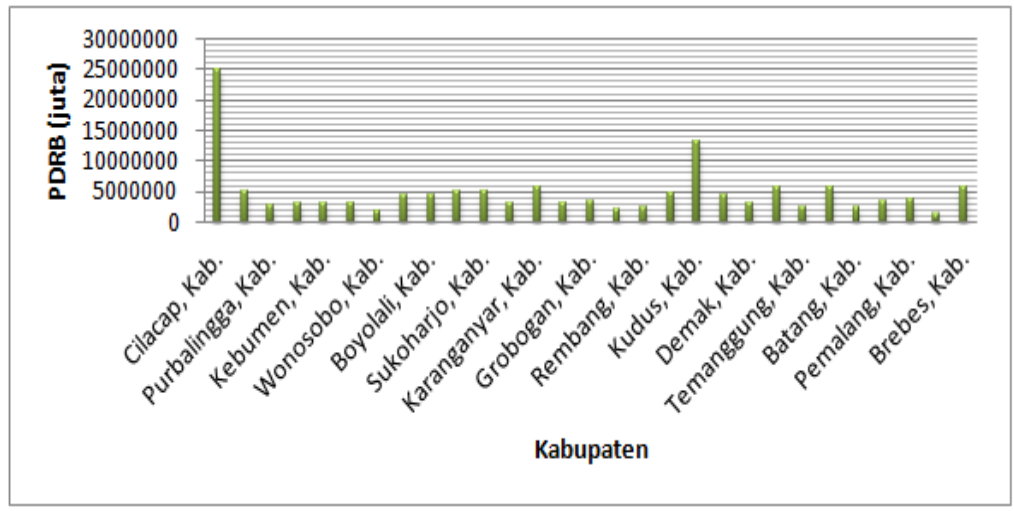

Sumber: Analisis Data Sekunder, World Bank 2011, dalam Nur Saudah (2015) 


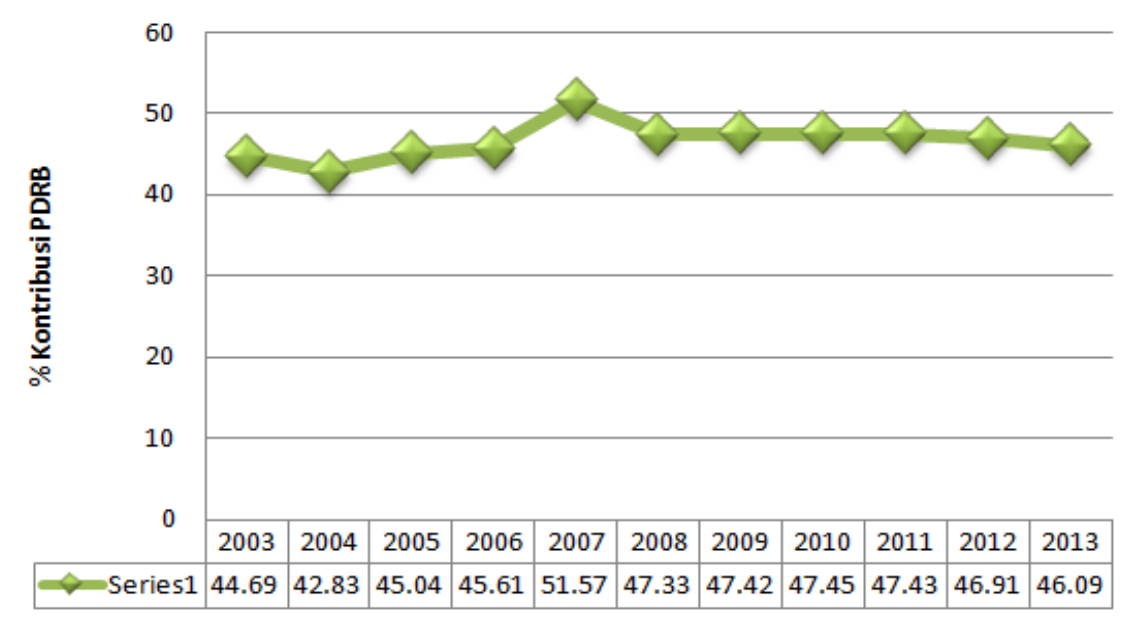

Sumber: Analisis data sekunder dalam Nur Saudah, 2015

Gambar 2

\section{Persentase Kontribusi Sektor Pertanian Terhadap PDRB Kabupaten Wonosobo}

tahun 2004 turun hingga 1,86\%. Tahun 2005 hingga 2007 terus mengalami perbaikan hingga mencapai kontribusinya tertinggainya di angka $51,57 \%$ atau lebih dari separuh PDRB Kabupaten Wonosobo ditopang oleh sektor pertanian.

Meskipun menjadi sektor unggulan, namun sejak tahun 2010 hingga 2013 trennya cenderung mengalami penurunan. Jika hal ini dibiarkan, maka sektor pertanian meskipun menjadi sektor yang diunggulkan di Wonosobo, namun bisa jadi akan menjadi sektor yang tertinggal bila dibandingkan dengan wilayah lain di Jawa Tengah. Dengan kondisi demikian, maka sudah seharusnya pemerintah kabupaten Wonosobo lebih berkonsentrasi dan memberikan perhatian lebih untuk sektor pertanian agar tidak semakin terpuruk dan tertinggal.

Kelebihan dan Kelemahan Penerapan Otonomi Daerah dalam Tata Kelola Kebijakan Pembangunan Pertanian Kelebihan Penerapan Otonomi Daerah Adanya otonomi daerah akan membawa dampak positif bagi pengembangan perekonomian di Kabupaten Wonosobo. Sehingga pemerintah daerah dapat lebih leluasa dalam mengambil kebijakan pembangunan daerah dengan lebih ce- pat dan disesuaikan dengan kebutuhan masyarakatnya. Dalam hal perencanaan anggaran, pemerintah daerah juga dapat menganggarkan anggaran belanja daerah melalui postur APBD. Termasuk dalam urusan pembangunan sektor pertanian, pemerintah Kabupaten Wonosobo tentunya mempunyai otoritas dalam perencanaan kebijakan hingga implementasinya.

Pemberlakuan otonomi daerah memberikan keleluasaan ruang gerak (kewenangan) pemerintah daerah dalam merencanakan dan melaksanakan kebijakan dan program yang sesuai dengan potensi daerah yang dimiliki. Pengelolaan sumberdaya yang dilakukan secara bertanggungjawab dan penuh kehati-hatian oleh pemerintah/pengampu kebijakan, yang didukung peran aktif masyarakat setempat sangat berpotensi mengurangi kesenjangan yang semakin melebar di segala sektor. Tentunya ini menjadi nilai lebih dari otonomi daerah, setiap kepala daerah yang visioner dan mempunyai banyak inovasi tentunya akan semakin mempercepat proses pembangunan sektor pertanian daerah.

Kelemahan Penerapan Otonomi Daerah Penerapan otonomi juga mempunyai kelemahan, karena dimungkinkan sering terjadi pergantian kebijakan ketika terjadi perpin- 
dahan tampuk kepemimpinan. Di kabupaten Wonosobo juga mengalami perubahan tata kelola pemerintahan, yang tentunya harus disikapi secara bijak oleh kepala daerah yang menjabat setelahnya, mengingat perombakan struktur pemerintahan yang ada di kabupaten Wonosobo terjadi di akhir masa jabatan. Sehingga pemerintahan yang saat ini bertugas mempunyai tanggungjawab lebih untuk melanjutkan proses pembangunan di sektor pertanian dapat berjalan secara efektif, efisien dan tentunya memberikan dampak yang signifikan yaitu peningkatan kesejahteraan masyarakat di Wonosobo.

Kesejahteraan masyarakat $\mathrm{di}$ Wonosobo yang sebagian besar adalah petani merupakan tujuan utama dari pembangunan sektor pertanian, hal tersebut takkan tercapai apabila setiap penggantian tampuk kepemimpinan di iringi pula dengan penggantian kebijakan di dalam tata kelola pemerintahan, karena hal ini akan berpengaruh terhadap cara kerja lembaga/ instansi terkait dalam menjalakan tugas pokok fungsinya, dan perlu diingat bahwa sektor pertanian return-nya tergolong lama sehingga idealnya setiap kebijakan yang diambil mengenai sektor pertanian haruslah kebijakan yang berkelanjutan dan tidak putus di tengah perjalanan.

Pada beberapa kasus penerapan otonomi daerah menunjukkan gejala yang overdosis, seperti dikatakan Ratnawati (2011) bahwa Implementasi kebijakan otonomi daerah menunjukkan penekanan berlebihan pada desentralisasi. Hal ini menimbulkan irasionalitas dalam penyelenggaraan birokrasi pemerintahan. Terbukti dengan tak membaiknya kondisi ekonomi masyarakat akibat ketidakcakapan pejabat daerah dalam mengelola pemerintahan dan perekonomian di daerah.

Saat ini, kesenjangan semakin terlihat antara golongan kelas bawah, kelas menengah dan juga kelas atas. Kelemahan lain dari otonomi daeah ialah beberapa instruksi pemerintah pusat kadang tidak tersampaikan dengan sempurna di daerah sehingga sehingga tujuan utama program pembangunan sulit tercapai.

\section{Ego Kepemimpinan Terhadap Pemban- gunan Sektor Pertanian}

Pengambilan keputusan merupakan kunci dari kepemimpinan, oleh karena itu antara kepemimpinan dengan pengambilan keputusan mempunyai hubungan keterkaitan, meskipun dalam perilaku kepemimpinan menimbulkan berbagai macam gaya kepemimpinan yang one man show, gaya kepemimpinan konsultatif, pendelegasian dan musyawarah (Manalu, 2015).

Tentunya yang menjadi harapan dan yang dicita-citakan adalah sosok kepala daerah yang mengedepankan musyawarah dalam setiap pengambilan keputusan, namun hal ini jarang terjadi di era demokrasi, dikarenakan banyak sekali kepentingan kelompok atau elit politik dibalik setiap pengambilan keputusan seorang pemimpin.

Dari berbagai macam permasalahan tersebut, apabila para kepala daerah memiliki leadership yang dapat melaksanakan fungsi serta peran kepemimpinannya secara harmonis dan disesuaikan dengan potensi daerahnya, maka permasalahan khususnya yang ada pada sektor pertanian akan tertangani secara lebih komprehensif.

Keberhasilan maupun kegagalan sebuah kebijakan pembangunan pertanian yang kaitannya dengan ketahanan dan kemandirian pangan sangat dipengaruhi berbagai faktor diantaranya adalah efektifitas yang meliputi aspek perencanan, pelaksanaan, pengawasan, pengendalian dan koordinasi berbagai kebijakan program. Kurang efektifya program-program yang dicanangkan oleh pemerintah dikarenakan setiap perencanaan mayoritas bersifat topdown dan belum memperhatikan kebutuhan serta aspirasi masyarakat yang ada di daerah. Harapan besar, dengan adanya pembagian wewenang yang jelas, maka pembangunan di berbagai sektor akan lebih terarah dan sesuai dengan kebutuhan lapangan.

Memang tidak dipungkiri bahwa desentralisasi juga menimbulkan ego pemimpin wilayah dalam memimpin di era kepemimpinannya. Idealnya, kepemimpi- 
nan tahun sebelumnya dapat menjadi inspirasi untuk perbaikan di masa pemerintahan yang akan datang, karena belajar dari tata kelola pemerintahan sebelumnya. Pun ini berlaku bagi yang sedang memimpin agar meninggalkan kebijakan yang berkesinambungan dan tidak meninggalkan kebijakan yang justru memberatkan dan membebani kepemimpinan penerusnya.

\section{SIMPULAN}

Penerapan otonomi daerah dan otoritas kepeminpinan kepala daerah memberi dampak terhadap perubahan kebijakan sektor pertanian di Wonosobo. Penerapan otonomi daerah mempunyai kelebihan dan kelemahan. Yang menjadi kelebihan antara lain, (1) menjadi motivasi dan inspirasi bagi setiap pemimpin daerah untuk berinovasi dalam mensejaterahkan rakyat. (2) Pemberlakuan otonomi daerah memberikan keleluasaan ruang gerak (kewenangan) pemerintah daerah dalam merencanakan dan melaksanakan kebijakan dan program yang sesuai dengan potensi daerah yang dimiliki Kelemahan dimungkinkan sering terjadi pergantian kebijakan ketika terjadi perpindahan tampuk kepemimpinan dan adanya disharmoni kebijakan dan program akibat ego politik dan perbedaan gaya kepempinan.

\section{DAFTAR PUSTAKA}

BPS. 2014. Jawa Tengah Dalam Angka 2014. Pemerintah Provinsi Jawa Tengah

Esther, Aphrodite dan Lexy. 2015. Sektor Pertanian Merupakan Sektor UngguIan Terhadap Pembangunan Ekonomi Provinsi Maluku. Agriekonomika, 4(2), 210- 220

Hermanto. 2013. Harmonisasi Kebijakan Pangan Nasional dan Daerah. Forum Penelitian Agro Ekonomi, Pusat Sosial Ekonomi dan Kebijakan Pertanian.
Kore, Jefri Wuru. 2015. Anomali Otonomi Daerah. http://jefririwukore.blogspot. co.id/2015/01/anomali-otonomi-daerah.html. Diakses tanggal 13 Oktober 2016.

Manalu, Simon. 2015. Konsep Otonomi Daerah Good Governance dan Reinventing Government dalam Pembangunan Daerah. http://www. kompasiana.com/konsep-otonomidaerah-good-governance-dan-reinventing-government-dalam-pembangunan-daerah. Diakses tanggal 14 Oktober 2015.

Mayrowani, Henny. 2012. Pembangunan Pertanian Pada Era Otonomi Daerah : Kebijakan dan Implementasi. Jurnal Forum Penelitian Agro Ekonomi, 30 (1), 31-47.

Rachbini, J Didik. 2010. Kebijakan dan Kepemimpinan. Koran Kompas Jumat, 9 Juli 2010.

Ratnawati,Tri. 2011. Otonomi Daerah Dianggap Masih Masih Memunculkan Egoisme Daerah https://m.tempo.co/ read/news/2011/10/11/173360885/ otonomi-daerah-dianggap-masihmemunculkan-egoisme-daerah. Diakses tanggal 13 Oktober 2016.

Saudah, Nur. 2015. Strategi Pengembangan Sektor Pertanian di Wonosobo. Tesis. Program Magister Manajemen Agribisnis (MMA) Universitas Gadjah Mada. Yogyakarta.

Wicaksono, Arditya. 2012. Optimalisasi Kepemimpinan Nasional dalam Melaksanakan Kebijakan Distribusi Pangan Dapat Mewujudkan Ketahanan Nasional. Agriekonomika, 1(1), 3646

Wordbank. 2011. Indonesia Database for Research and Economi Policy. http:// databank.worldbank.org. Diakses tanggal 10 September 2014. 